\title{
The Quantitative Research of Regional Hydrologic Drought Driving Factors in Weihe River Basin of China
}

\author{
Liu Wenkun ${ }^{1,2, ~ a, ~ L i u ~ Z h i p i n g ~}{ }^{1, b}$, Pei Yuansheng ${ }^{1, c}$, Zhai Jiaqi ${ }^{1, d}$ \\ ${ }^{1}$ China Institute of Water Resources and Hydropower Research, A-1 Fuxing Road, Beijing, China \\ ${ }^{2}$ PowerChina Kunming Engineering Corporation LTD, $115^{\#}$ Renming East Road, Kunming, China

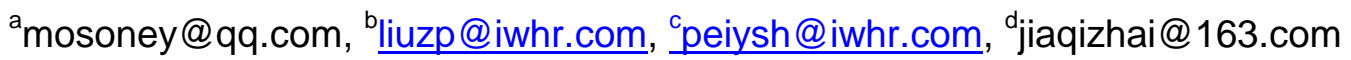

Keywords: regional drought; hydrologic drought; SWRI; drought quantitative analysis; WACM.

Abstract. In previous research, the drought evaluation index did not consider the influence of groundwater resources. This study select the standard water resources index (SWRI), and put the impacts of surface water resources, soil water resources and groundwater resources together into SWRI. A regional drought quantitative assessment method was established which included WACM hydrologic simulation system, SWRI evaluation system and regional drought characteristics analysis system. Through the scenarios analysis, 3 driving factors, climate change, soil resources utilization, water resources utilization, had shown their quantitative hydrologic drought affection contributions as $58.7 \%, 17.9 \%$ and $23.4 \%$ in Weihe river basin, China.

\section{Introduction}

At present, the research object of hydrological drought is surface water resources, or natural runoff. ${ }^{[1,2]}$ The original meaning of hydrological drought is water shortage of the entire hydrological system. [1] While in the complex water circulation system, especially in the area with intense human development and utilization of water resources, a large part of the production and living and ecological water comes from groundwater ${ }^{[3,4]}$. It is not proper to judge whether hydrological drought or not by the single factor of surface water resources.

In previous studies ${ }^{[5 \sim 7]}$, some scholars have studied the influence of climate change on hydrological drought and they focus on the change of land utilization or separately study human water use to measure the effects on hydrological drought by deducting the runoff water directly but little study in the water resources development and utilization of human activities on hydrological drought from the perspective of the whole water cycle system. It is a collection of a series of activities: human water use, agricultural practices, irrigation system, buildings of the reservoir dam, water resources scheduling, etc. Hydrological drought is influenced by the water resources development and utilization by means of changing surface runoff and soil hydrology state and the effect to the water cycle of the whole system.

\section{Methodology}

Regional Hydrologic Drought Assessment Method. The surface water and groundwater are closely related in the basin scale, the change of runoff generation and confluence often accompanied by the change of groundwater movement. Meanwhile, in the condition of water resources development and utilization, the understanding of the regional hydrologic drought have changed from 'the lack of water in the river' to 'the lack of water resources in the basin'. It ought to incorporate the groundwater to the hydrologic drought evaluation index. So this paper suggest a new hydrologic drought evaluation index called standard water resources index (SWRI) that based on the total water resources quantity(include surface water and groundwater). The calculation method of SWRI referred to the standard runoff index (SRI), used total water resources quantity to instead of the surface runoff in SRI. The hydrologic drought hierarchies is seen as Table 1. 
Table 1 the hydrologic drought hierarchies

\begin{tabular}{lll}
\hline status & SWRI & level \\
\hline 0 & $-0.5<S W R I$ & No Drought \\
1 & $-1.0<S W R I \leq-0.5$ & Mild \\
2 & $-1.5<S W R I \leq-1.0$ & Moderat \\
3 & $-2.0<S W R I \leq-1.5$ & Severe \\
4 & $S W R I \leq-2.0$ & Extra \\
\hline
\end{tabular}

For the assessment of regional hydrologic drought, after calculation of drought index of in each assessment unit at different time periods in the research area, then it is turn to the drought identification. Drought identification is to identify an evaluation object at a certain period whether in the drought state or not. The popular process is threshold method that based on the theory of run ${ }^{[8]}$, which regard the evaluation index of objects that beyond a certain threshold value as the object in a state of drought.

When completed the drought identification, we can use drought duration, drought area, drought severity to characterize a regional drought event, and use them to measure the severity of the drought event ${ }^{[5]}$, and quantitatively analyze the response of all kinds of driving scenario to the hydrological drought.

Driving Mechanism of Hydrologic Drought. The characterization of hydrologic drought is the balance abnormal of surface water or groundwater. Within the water cycle system including human activities, the income of surface water moisture is mainly from the rainfall, secondly from the groundwater discharge or diversion, when the expenses of surface water include evapotranspiration, infiltration, human consumption and diversion. For the groundwater, the recharge is mainly from the precipitation infiltration, secondly from the runoff infiltration, lakes infiltration, irrigation infiltration, and living water infiltration, when the expenses of groundwater include artificial exploitation, phreatic water evaporation and mountain groundwater discharge. These interrelated processes make the surface water and groundwater in a dynamic change status, when one process is abnormal by disturbance, the abnormal state of surface water and groundwater occurs, as it results in a decrease of total water resources in the system, the hydrologic drought is formed. Therefore, the factors that can affect those processes are the main driving factors of the hydrologic drought, seen as Figure 1, which could be summarized as three aspects:

a) Climate Change. At present, the decrease of precipitation is the main trend of global climate change, it may directly cause the hydrological drought. Meteorological drought represents in abnormal imbalance of precipitation and evaporation.

b) Land Use Change. Underlying surface condition is closely related to the runoff and evaporation process, mainly embodied in ways of land use change caused by human activity.

c) Development and Utilization of Water Resources. Growing rigid demand for economic and social development to water resources and the growing degree of human disturbance to the water resources

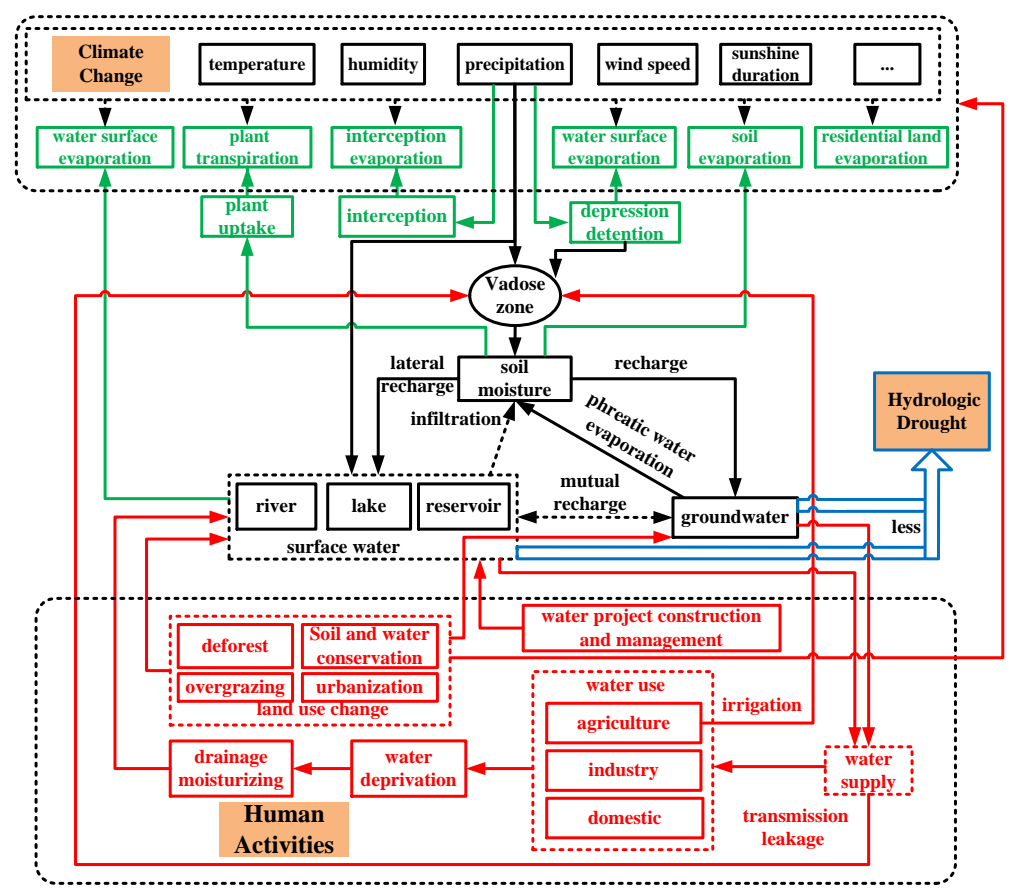
system will directly affect hydrological drought.

Fig.1 the driving factors and their driving mechanism of hydrologic drought

Study Area and Assessment Secnarios. In the study, Weihe basin is selected to analysis and calculation, which covers 0.135 million $\mathrm{km} 2$ and mountain area accounts 0.114 million $\mathrm{km} 2$ and plains area accounts 0.023 million km2. It flows through Gansu, Ningxia, Shaanxi provinces (area) 
and located in the transition zone of arid and humid regions with a hot rainy season. Mean annual precipitation is $589 \mathrm{~mm}$ and the basin surface evaporation is $660 \sim 1600 \mathrm{~mm}$, and the land surface evaporation is about $500 \mathrm{~mm}$.

Table 2 the quantitative simulation scenarios of hydrologic drought

Based on the climate change,
land use change and water
resources development and
utilization of three types of driving
factors, in this paper, it chooses the
way of the water cycle model
simulation by setting up three

\begin{tabular}{cccc}
\hline $\begin{array}{c}\text { the period of the } \\
\text { conditions }\end{array}$ & $\begin{array}{c}\text { meteorological } \\
\text { conditions }\end{array}$ & $\begin{array}{c}\text { land use } \\
\text { conditions }\end{array}$ & $\begin{array}{c}\text { development and } \\
\text { utilization of water } \\
\text { resources } \\
\text { conditions }\end{array}$ \\
\hline based scenario & $1971 \sim 1980$ & 1980 & $1971 \sim 1980$ \\
compared scenario I & $2001 \sim 2010$ & 1980 & $1971 \sim 1980$ \\
compared scenario II & $1971 \sim 1980$ & 2005 & $1971 \sim 1980$ \\
compared scenario III & $1971 \sim 1980$ & 1980 & $2001 \sim 2010$ \\
\hline
\end{tabular}
comparative analysis programs and a benchmark program to simulate analysis of three kinds of driver after each change of hydrologic drought situation in order to quantitatively evaluate the effect of various kinds of drivers to hydrologic drought. All conditions of benchmark scenarios are used before the three kinds of drivers. In the contrast scenario I, the climate change while other conditions remain unchanged, then we can analyze the driving effects of climate on the hydrologic drought. Similarly, land use change separately in contrast scenario II and water resources development changes separately in contrast scenario III.

WACM Model. This study selected WACM model for river basin water cycle simulation and calculated water resources in each assessment unit evaluation period. WACM Model (Water Allocation and Cycle Model) is currently applied to Weihe basin, Heihe basin and the Ningxia region and strong in simulating water cycle process in human activity, which is a river basin water cycle model based on natural and artificial composite water cycle system, can simulate the response to climate changes and human activities of river basin in a whole water cycle comprehensively. The model can be simulated the effect of the development and utilization of water resources, especially irrigation farmland and drainage systems to the entire state of the water cycle, which can use to analyze the driving effect of the drought of the water resources development and utilization.

\section{Data}

Basin Slope Surface Discretization. Firstly, it is necessary to slope-surface discrete the Weihe basin according to the calculation precision requirements of each drought assessment unit and WACM features of the model. We chose NASA's (National Aeronautics and Space Administration, NASA) newly released global DEM data of 2009 as the DEM model data. Data sampling precision and elevation accuracy are $30 \mathrm{~m}$ and $7 \sim 14 \mathrm{~m}$, respectively. River water system is shown in Table 3 extracted by ArcGIS platform and there are 247 sub basins according to the corresponding classification of extraction of river network water system. Then we subdivide the sub basin by administrative area. As the division ways difference between mountains and plains of the WACM model, the largest two plains (the Guanzhong plain and Qingyang plain) were selected to grid cell divide into $1 \mathrm{~m}$ by $1 \mathrm{~m}$ in Weihe basin while other mountains were divided by irregular unit. Finally, the cycle simulation space discrete figure of Weihe basin water was shown in Table 4 after definite the model space of drained and irrigated water canalization, the reservoir dams and irrigation wells as such considering the large and medium-sized irrigation areas and types of irrigation in Weihe basin. The Guanzhong plain slope discrete figure was shown in Figure 4(a). The entire basin slope discrete figure was shown in Figure 2.

Data of Driving Scenarios.Meteorological data: the daily precipitation, daily average temperature, daily maximum and minimum temperature, daily sunshine hours, daily average wind speed and the average relative humidity and so on. Meteorological data needed comes from "Chinese Ground Weather Data Log Data Set (V3.0)"of China meteorological data sharing service. As a result, 37 relevant weather stations in Weihe basin were selected according to Thiessen polygon method in this 
evaluation analysis and calculation, and two period of time namely 1971 1980 and 2001 2010 were selected and daily meteorological data was distributed to each drought assessment unit in Kriging interpolation method.

The land use data: land use type data is based on data of Chinese land use published by Data Center for Resources and Environmental Sciences Chinese Academy of Sciences (RESDC), and extracted, eclassified, corrected to the distributed information of land use space of the north of Weihe in 1980 and 2005.

Data of water resources development and utilization: the degree of development and utilization of water resources and conditions were mainly extracted from all kinds of water resources planning, reporting, including

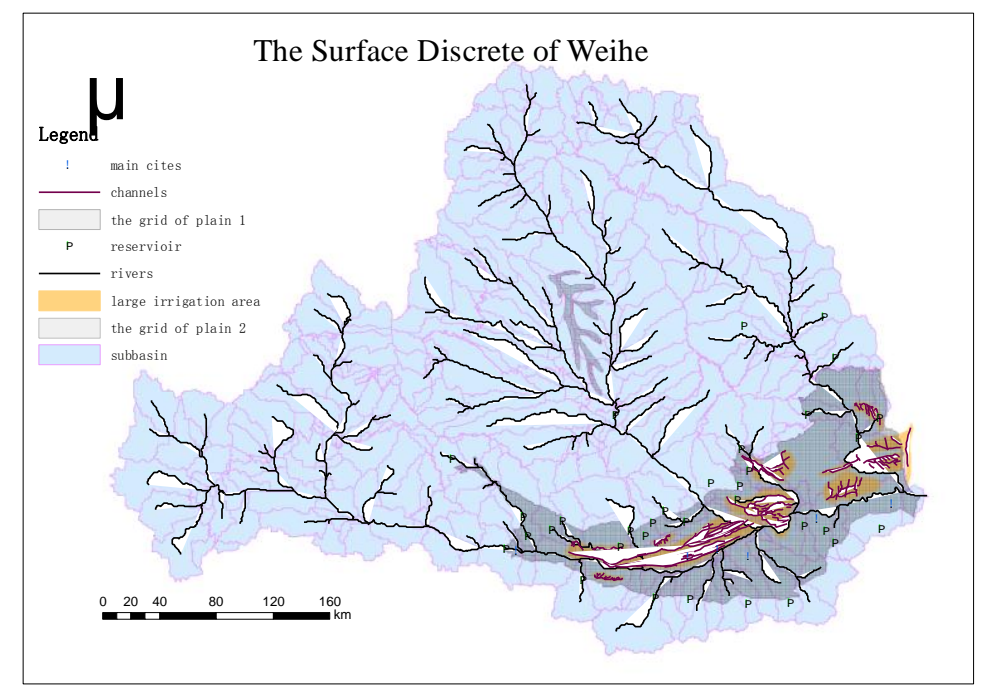

Fig.2 the surface discrete of Weihe

two periods when changes arise or not. Such as the water quantity allocation scheme designing of Weihe (2012), the report of large intake of Weihe basin(2007), the hydrological geology of Guanzhong basin, the supporting of large irrigated areas and the planning of water saving, The integrated water resources planning of Yellow River basin(2009), the report of large and medium-sized reservoirs peak scheduling of Weihe basin in Shanxi.

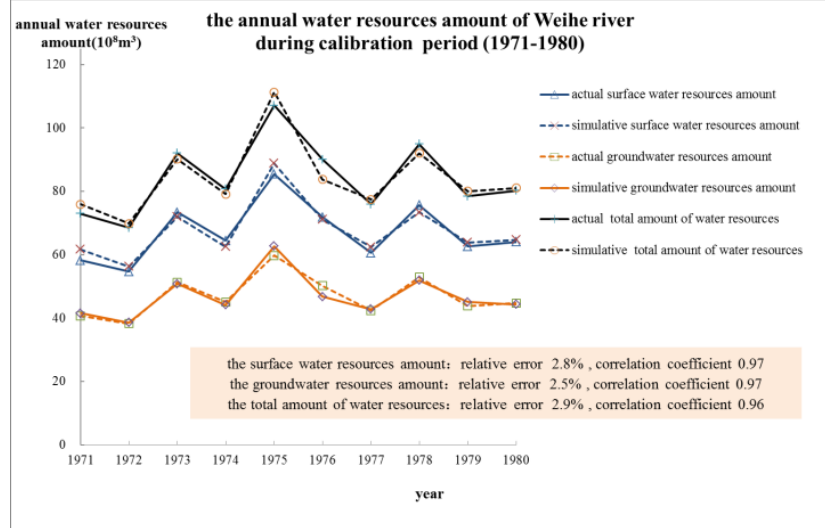

(a) the calibration of water resources amount

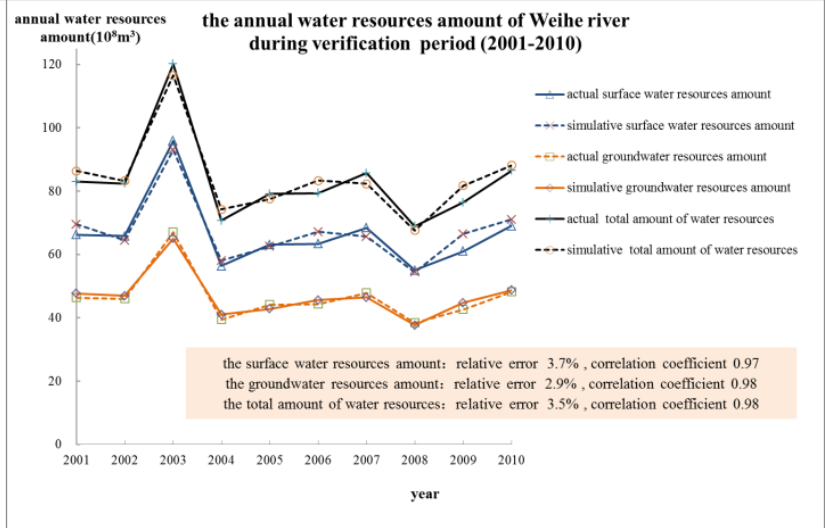

(b) the verification of water resources amount Fig.3 the calibration and verification of water resources amount

\section{Results and Discussion}

The Change of Water Resources. From simulation calculation of the model, the average annual surface water resources, groundwater resources and total water resources of the entire basin of the benchmark solution and the three kinds of contrast solutions are shown in Table 4. It can be concluded that the influence of climate changes on river basin water resources is the largest. From statistical calculations of the major meteorological factors in climate changes solution, the average annual precipitation of the whole basin decreased by $6.7 \%$ after changes and temperature increased by $3.2 \%$, the wind speed decreased by $8.0 \%$, relative humidity decreased $3.9 \%$ and sunshine duration decreased $3.5 \%$. Precipitation reduces led directly to the surface water and groundwater recharge and the amount of evaporation in the whole basin increased shown in the process of model calculation. Then the total water resources reduced considerably.

Considering land use change, the total water resources have been decreased as a result, but the groundwater resources increased slightly. The six kinds of the main types of land use change analysis were shown in Table 3. The main trend of land use change was grass land to forest and cultivated land 
decreased while residential and working land increased slightly. The increasing of forest land would improve soil water retention performance and might reduce the production flow of the surface water and increase the infiltration recharge of groundwater. Then decrease the surface water resources and increase groundwater resources as a result. On the whole, the total water resources decreased.

Table 3 the change of water resources

\begin{tabular}{|c|c|c|c|c|c|c|}
\hline \multirow[b]{2}{*}{$\begin{array}{l}\text { Annul Water Resources } \\
\qquad\left(\times 10^{8} \mathrm{~m}^{3}\right)\end{array}$} & \multicolumn{3}{|c|}{ Value } & \multicolumn{3}{|c|}{ Change } \\
\hline & $\begin{array}{l}\text { Surface } \\
\text { Water }\end{array}$ & $\begin{array}{l}\text { Ground } \\
\text { water }\end{array}$ & Total & $\begin{array}{l}\text { Surface } \\
\text { Water }\end{array}$ & $\begin{array}{l}\text { Ground } \\
\text { water }\end{array}$ & Total \\
\hline based scenario & 65.10 & 45.52 & 81.59 & & & \\
\hline compared scenario I & 60.22 & 43.52 & 76.04 & $-7.5 \%$ & $-4.4 \%$ & $-6.8 \%$ \\
\hline compared scenario II & 63.47 & 45.84 & 80.20 & $-2.5 \%$ & $0.7 \%$ & $-1.7 \%$ \\
\hline compared scenario III & 62.82 & 46.25 & 79.39 & $-3.5 \%$ & $1.6 \%$ & $-2.7 \%$ \\
\hline
\end{tabular}

As for the result of the development and utilization of water resources, the natural water cycle pattern might have changed after the development and utilization of water resources. In particular, ridge of the cultivated land could hamper the normal surface runoff and increase infiltration and evaporation and decrease the surface water resources and increase groundwater resources as a result.

Drought Contribution of Each Driving Factors. According to the proposed regional drought evaluation index and regional drought characteristics calculation method, the benchmark solution and the three kinds of contrast solutions were taken the drought evaluation. Relative driving action results of each drought driver were analyzed and shown in Table 4.

Table 4 drought contribution of each driving factors

\begin{tabular}{|c|c|c|c|c|c|}
\hline \multicolumn{2}{|c|}{ Drought Characteristics Index } & $\begin{array}{l}\text { Duration } \\
\text { /month }\end{array}$ & $\begin{array}{c}\text { Area } \\
1 \%\end{array}$ & severity & $\begin{array}{l}\text { integrated } \\
\text { severity }\end{array}$ \\
\hline \multirow{4}{*}{ Result } & Based scenario $\mathrm{x}_{0}$ & 3.64 & 0.54 & 0.78 & 2.56 \\
\hline & Climate Change scenario $\mathrm{I}_{1}$ & 5.82 & 0.42 & 1.12 & 3.24 \\
\hline & Landuse Change scenario II $\mathrm{x}_{2}$ & 4.00 & 0.56 & 0.84 & 2.77 \\
\hline & $\begin{array}{c}\text { Water Utilization Change } \\
\text { scenario III } x_{3} \\
\end{array}$ & 4.20 & 0.56 & 0.85 & 2.83 \\
\hline \multirow{4}{*}{ Change } & $\Delta \mathrm{x}_{1}=\mathrm{x}_{1}-\mathrm{x}_{0}$ & 2.19 & -0.12 & 0.34 & 0.68 \\
\hline & $\Delta \mathrm{x}_{2}=\mathrm{x}_{2}-\mathrm{x}_{0}$ & 0.36 & 0.02 & 0.06 & 0.21 \\
\hline & $\Delta \mathrm{x}_{3}=\mathrm{x}_{3}-\mathrm{x}_{0}$ & 0.56 & 0.02 & 0.07 & 0.27 \\
\hline & $\Delta \mathrm{x}=\left|\Delta \mathrm{x}_{1}\right|+\left|\Delta \mathrm{x}_{2}\right|+\left|\Delta \mathrm{x}_{3}\right|$ & 3.11 & 0.16 & 0.47 & 1.16 \\
\hline \multirow{3}{*}{$\begin{array}{l}\text { Contribution } \\
\qquad(\%)\end{array}$} & $\eta_{1}=\Delta x_{1} / \Delta x$ & $70.2 \%$ & $-77.1 \%$ & $72.5 \%$ & $58.7 \%$ \\
\hline & $\eta_{2}=\Delta x_{2} / \Delta x$ & $11.7 \%$ & $12.1 \%$ & $12.4 \%$ & $17.9 \%$ \\
\hline & $\eta_{3}=\Delta x_{3} / \Delta x$ & $18.1 \%$ & $10.9 \%$ & $15.0 \%$ & $23.4 \%$ \\
\hline
\end{tabular}

a) From the driving factors of hydrological drought driving direction, climate changes, land use change and water resources development and utilization of Weihe basin played an intensifying role to hydrological drought. In other words, those three factors would extend drought duration, increase drought area and intensity in different degrees.

b) From various factors impact on hydrological comprehensive drought, climate changes were a major driving force of the change of the hydrologic drought which accounted for $58.7 \%$ after calculating the same amount of the drought intensity. The water resources development and utilization factor ranked the second which accounted for $23.4 \%$. The land use change ranked the latter which accounted for $17.9 \%$. Considering the water resources development and utilization factor and the land use change together, it was found that the relative driving effect of human activities on the hydrological drought is $41.3 \%$ and it was still less than factors of climate changes.

c) From the influence of various factors on the hydrologic drought duration and intensity, its change trends are basically identical with the same amount of the drought intensity. From the 
influence of hydrologic drought area, it might be related to the increasing local extreme drought event of river basin when hydrologic drought area reduced after climate changes.

d) Climate changes, land use change and water resources development and utilization of Weihe basin all played an intensifying role on hydrological drought. Among them, climate changes are the most important driving factor to hydrological drought. Not only the same amount of the drought intensity, the drought area, intensity and duration $i$ also influenced by climate changes at the largest extent.

\section{Conclusions}

In this study, begin with an expansion of the connotation of the hydrologic drought, the river basin drought driver analysis was staged based on the water cycle model in Weihe basin around the hydrologic drought driver factors and added groundwater resource in hydrologic drought index creatively. Conclusions were conducted as follows:

a) Climate changes, land use change and water resources development and utilization of change will lead to a drop in river basin water resources and increase hydrologic drought event, then intensify hydrologic drought.

b) Climate changes are the main factor which leads to drought event of Weihe basin, accounted for $58.7 \%$.

The influence of human activity is not the right major cause which leads to drought event.

In the future, it will be proper to continue conducting other types of research of drought based on the water cycle model considering the three driving factors in this paper. Such as agricultural drought in a river basin based on soil water content for the drought index and so on.

\section{Acknowledgements}

This work was financially supported by National Natural Science Youth Foundation of China (No.51309249) and National Natural Science Foundation of China (No.51379216).

\section{References}

[1] Dracup J A, Lee K S, Paulson E G. On the statistical characteristics of drought events [J]. Water Resources Research, 1980, 16(2): 289-296.

[2] Tallaksen L M, Hisdal H, Henny A J, et al. Space-time modelling of catchment scale drought characteristics[J]. Journal of Hydrology, 2009, 375:363-372.

[3] Mishra A K, Singh V P, Desai V R. Drought characterization: a probabilistic approach [J]. Stochastic Environmental Research and Risk Assessment. 2009, 23(1):41-55.

[4] Mishra A K, Desai V R. Spatial and temporal drought analysis in the Kansabati River Basin, India [J]. International Journal of River Basin Management. 2005b, 3 (1):31-41.

[5] Desalegn C E,Mukand S B, Ashim D G. Drought Analysis in the Awash River Basin, Ethiopia[J]. Water Resources Management, 2010, 24:1441-1460.

[6] Szalai S, Szinell C, Zoboki J. Drought monitoring in Hungary. In: Early Warning Systems for Drought Preparedness and Drought Management, WMO, Geneva, 2000, 161-176

[7] Eleanor J B, Simon J B. Regional drought over the UK and changes in the future [J].Journal of Hydrology, 2010, 394:471-485

[8] Keyantash J, Dracup J A. The quantification of drought: an evaluation of drought indices. The drought monitor [J]. Bulletin of the American Meteorological Society, 2002, 83 (8):1167-1180. 